\title{
Analisis Kesalahan Berdasarkan Prosedur Watson dalam Menyelesaikan Soal Matematika Materi Lingkaran Ditinjau dari Adversity Quotient Siswa SMP Darul Aitam Palembang
}

\author{
Karimawati'), Ali Syahbana $^{2)}$, Tika Dwi Nopriyanti' ${ }^{3)}$ \\ 1,2,3) Universitas PGRI Palembang, Indonesia \\ Email: karimawatiii@gmail.com,syahbanaumb@yahoo.com, \\ tikadwinoprianti@univpgri-palembang.ac.id
}

\begin{abstract}
This study aims to describe the types of mistakes students make in completing the questions on the circumference and area of the circle as seen from the students' Adversity Quotient. There are 3 types of Adversity Quotient, namely Climbers (high, enough), Campers and Quitters (insufficient, low). In this study using a qualitative descriptive method. Data collection techniques in this study are in the form of a questionnaire (AQ), a written test in the form of a description of 9 questions and documentation. This research was conducted at SMP Darul Aitam Palembang, with the subject, namely all students of class IX.3, totaling 30 students, to analyze the types of students' errors in solving math problems regarding the circumference and area of the circle based on the Adversity Quotient they have. The results showed that 1) students who had AQ of the Climbers type made mistakes in indirect manipulation (UM) in the process of solving the given questions, 2) students who had AQ of the Campers type made mistakes, namely inappropriate data (IN) ), omitted conclusion (ON), undirected manipulation (UN), incorrect conclusions (above other / AO). 3) students who have AQ Quitters type make inappropriate data errors (innappropriate data / IN), inappropriate procedures (IP), omitted data (OD), skills hierarchy problems (SHP), lost conclusion (omitted conclusion / OC), response level conflict (RLC),
\end{abstract}

Keywords : Adversity Quotient, Student Error, Watson's Error Procedure

\begin{abstract}
ABSTRAK
Penelitian ini bertujuan untuk mendeskripsikan jenis kesalahan siswa dalam menyelesikan soal materi keliling dan luas lingkaran ditinjau dari Adversity Quotient (AQ) siswa. Terdapat 3 tipe AQ yaitu Climbers (tinggi, cukup), Campers dan
\end{abstract}


Quitters (kurang, rendah). Penelitian ini menggunakan metode deskriptif kualitatif. Teknik pengumpulan data berupa Angket (AQ), tes tertulis berjumlah 9 soal uraian dan dokumentasi. Penelitian ini dilakukan di SMP Darul Aitam Palembang, dengan subjek seluruh siswa kelas IX.3 berjumlah 30 orang siswa untuk dianalisis jenis kesalahan siswa dalam menyelesaikan soal matematika materi keliling dan luas lingkaran berdasarkan AQ yang mereka milliki. Hasil penelitian menunjukkan bahwa 1) siswa yang memiliki AQ pada tipe Climbers melakukan kesalahan manipulasi tidak langsung (undirected manipulation/UM) dalam proses menyelesaikan soal yang diberikan, 2) siswa yang memiliki AQ tipe Campers melakukan kesalahan yaitu data tidak tepat (inappropriate data/IN), kesimpulan hilang (omitted conclusion/ON), manipulasi tidak langsung (undirected manipulation/UN), kesimpulan tidak tepat (above other/AO). 3) siswa yang memiliki AQ tipe Quitters melakukan kesalahan data tidak tepat (innappropriate data/IN), prosedur tidak tepat (inappropriate procedure/IP), data hilang (omitted data/OD), masalah hirarki keterampilan (skills hierarchy problem/SHP), kesimpulan hilang (omitted conclusion/OC), konflik level respon (response level conflict/RLC), manipulasi tidak langsung (undirected manipulation/UN) dan kesimpulan tidak tepat, tidak menjawab soal (above other/AO).

Kata Kunci : Adversity Quotient, Kesalahan Siswa, Prosedur Kesalahan Watson

\section{PENDAHULUAN}

Kemajuan ilmu pengetahuan dan teknologi dewasa ini menuntut manusia agar memiliki keahlian dan keterampilan dalam bidang tertentu.Untuk memiliki keahlian dan keterampilan tersebut tidak terlepas dari dunia pendidikan. Pendidikan merupakan suatu proses kegiatan manusia khususnya dalam mengarahkan perkembangan kepribadian dan kemampuan, baik pada orang lain maupun pada diri sendiri, melalui pendidikan nalar, keterampilan dan kematangan pada manusia. Belajar merupakan pendidikan yang salah satunya ditempuh di bangku sekolah. Belajar di sekolah berarti belajar semua mata pelajaran yang telah ditentukan diantaranya adalah matematika. Matematika adalah salah satu pelajaran yang sangat penting bagi manusia baik pada pendidikan dasar maupun untuk melanjutkan pendidikan ke tingkat yang lebih tinggi.

Matematika terdiri dari empat bahasan yaitu aljabar, aritmetika, analisis dan geometri. Menurut Nur'aini, Harahap, Badruzzaman, \& Darmawan (2017) geometri merupakan salah satu dari beberapa bidang matematika yang dianggap sulit bila dibandingkan dengan bidang-bidang yang lain. Geometri merupakan suatu pokok bahasan yang harus di pelajari dalam matematika karena tidak jarang kita temukan 
dalam kehidupan sehari-hari salah satu contohnya yaitu lingkaran. Salah satu materi yang dipelajari dalam pokok bahasan lingkaran yaitu keliling dan luas lingkaran

Namun pada kenyataannya siswa masih merasa kesulitan dalam menyelesaikan soal materi lingkaran, hal ini dilihat dari masih banyaknya siswa yang melakukan kesalahan-kesalahan dalam menyelesaikan soal materi lingkaran, hal ini sejalan dengan Lestari, Hasbi, \& Lefrida (2016) yang menyatakan bahwa kesalahankeslahan yang sering terjadi pada siswa saat menyelesaikan soal mengenai keliling dan luas lingkaran adalah (1) kesalahan konsep, yaitu kesalahan dalam menerapkan rumus lingkaran (2) kesalahan fakta, kesalahan dalam menulis satuan luas lingkaran serta salah saat menarik kesimpulan akhir jawaban (3) kesalahan prinsip, yaitu kesalahan ketika menafsirkan soal dan (4) kesalahan prosedural, yaitu kesalahan siswa saat melakukan perhitungan perkalian dan perpangkatan. Hal ini juga sejalan dengan penelitian Arifin (2011) yang menyatakan bahwa salah satu kesalahan yang dilakukan oleh siswa dalam menyelesaikan soal materi lingkaranyaitu kurangnya dalam memahami konsep. Hal ini dapat dilihat pada gambar berikut ini :

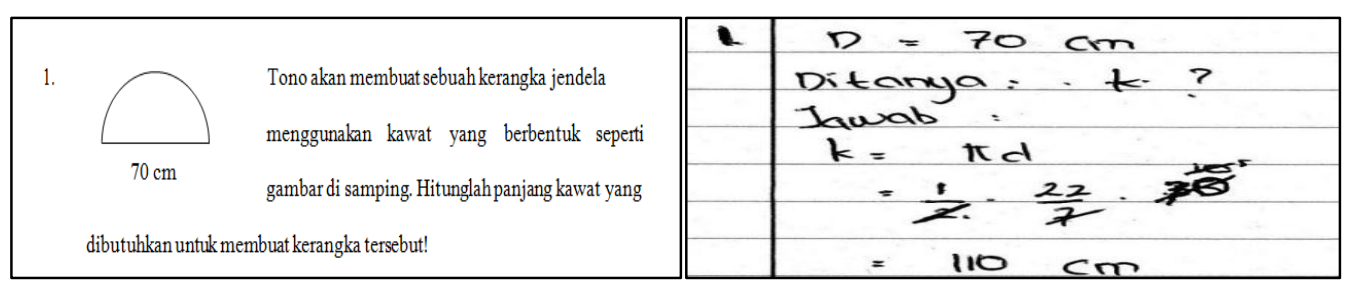

Gambar 1. Soal dan Jawaban Penelitian Arifin (2011)

Dari jawaban di atas menunjukkan bahwa siswa tersebut berusaha mengoperasikan pada level yang tepat serta menggunakan data yang tepat. Tetapi terdapat langkah yang hilang. Di dalam soal ditanya berapa panjang kawat tersebut tetapi dia hanya menjawab sampai pada tahap keliling lingkaran saja. Menghitung panjang kawat tidak dilakukan dikarenakan siswa tersebut kurang keterampilan tentang konsep keliling lingkaran. Berdasarkan hasil wawancara yang dilakukan dengan ibu Erliana, S.Pd yang merupakan salah satu guru matematika di kelas IX yang ada di SMP Darul Aitam Palembang, rata-rata nilai yang diperoleh siswa pada bangun datar khususnya materi lingkaran termasuk rendah. Jika dilihat dari ketuntasan siswa untuk materi lingkaran, ketidak tuntasan belajar mencapai sekitar $60 \%$ dari jumlah siswa. Siswa sering melakukan kesalahan dalam menyelesaikan soal-soal yaitu dalam memasukkan/menggunakan rumus keliling lingkaran, rumus 
luas lingkaran. Hal ini terjadi karena siswa lebih cenderung dalam menghapal rumus dalam menyelesaikan soal.

Berdasarkan hasil penelitian diatas terlihat bahwa terdapat kesalahankesalahan yang dilakukan oleh siswa dalam menyelesaikan soal. Kesalahankesalahan yang terjadi bisa dikarenakan rendahnya Adversity Quotient (AQ) yang dimiliki oleh siswa, hal ini sejalan dengan Wardiana (2014) yang menemukan adanya hubungan yang signifikan antara AQ dengan hasil belajar matematika. Matore (2015) juga mengemukakan bahwa AQ mempengaruhi terhadap hasil belajar. Berdasarkan penelitian tersebut dapat disimpulkan bahwa tingkatan AQ dapat mempengaruhi tinggi rendahnya hasil belajar siswa. Aspek dalam hasil belajar matematika salah satunya adalah kemampuan dalam menyelesaikan masalah.

Dalam menyelesaikan permasalahan, pada umumnya seseorang dapat berputus asa dan lemah, mereka berhenti berusaha apabila dihadapkan dengan permasalahan yang ada, padahal mereka belum benar-benar menguji kemampuannya. Mereka inilah yang dimaksud dengan Adversity Quotientnya rendah (Pratiwi, 2016).

Stolz (dalam Hidayat \& Sarinigsih, 2018) menyatakan bahwa Adversity Quotient (AQ) merupakan ketangguhan seseorang dalam menyelesaikan kesulitan yang ada dengan kecerdasan yang dia miliki dan dapat dilihat seberapa jauhkah seseorang tersebut mampu bertahan dalam suatu masalah yang sedang dihadapinya untuk diselesaikan. AQ memiliki tiga tipe yaitu Climbers, Campers dan Quitters.

Stolz (2000) mengklasifikasikan kategori pada setiap AQ sebagai berikut:

Tabel 1. Kategori Tingkat Adversity Quotient Berdasarkan Stolz

\begin{tabular}{cc}
\hline Kategorisasi & Skor \\
\hline Climbers (Tinggi) & $166-200$ \\
\hline Climbers (Cukup) & $135-165$ \\
\hline Campers & $95-134$ \\
\hline Quitters (Kurang) & $60-94$ \\
\hline Quitters (Rendah) & $0-59$ \\
\hline
\end{tabular}

Dengan adanya tipe AQ peneliti tertarik meneliti letak dan jenis kesalahan siswa dalam menyelesaikan soal berdasarkan dari AQ yang dimiliki siswa. Dengan menganalisis kesalahan-kesalahan tersebut diharapkan dapat mengetahui letak dan 
jenis kesalahan siswa tersebut dalam menyelesaikan soal matematika khususnya terkait materi keliling dan luas lingkaran. Informasi tentang kesalahan siswa dalam mengerjakan soal matematika dapat membantu guru dalam meningkatkan mutu pembelajarannya dengan menekankan hal-hal yang kurang dikuasai siswa dan diharapkan bisa menghindari kesalahan yang sama. Salah satu teori yang dapat digunakan untuk menganalisis kesalahan siswa yaitu teori Watson, hal ini sejalan dengan Saputri, dkk (2018) yang mengatakan bahwa prosedur kesalahan menurut Watson cocok digunakan untuk menganalisis kesalahan siswa pada mata pelajaran matematika maupun Ilmu Pengetahuan Alam (MIPA). Adapun kriteria kesalahankesalahan dalam mengerjakan soal berdasarkan Prosedur Watson (dalam Sari, 2018) yaitu: (1) Data tidak tepat (innappropriate data/ID), (2) Prosedur tidak tepat (inappropriate procedure/IP), (3) Data hilang (ommited data/OD), (4) Kesimpulan hilang (omitted conclusion/OC), (5) Konflik level respon(response level conflict/RLC), (6) Manipulasi tidak langsung (undirected manipulation/UM), (7) Masalah hirarki keterampilan (skills hierarchy problem/SHP), (8) Selain ke 7 kategori diatas (above other/AO).

Berdasarkan informasi di atas, untuk mengatasi hal tersebut maka peneliti memilih judul "Analisis Kesalahan Siswa Berdasarkan Prosedur Watson dalam Menyelesaikan Soal Matematika Materi Lingkaran Ditinjau Dari Adversity Quotient (AQ) Siswa SMP Darul Aitam Palembang". Tujuan penelitian ini adalah untuk mendeskripsikan dan menganalisis kesalahan siswa dari masing-masing tipe Adversity Quotient dalam menyelesaikan soal matematika pada materi keliling dan luas lingkaran berdasarkan prosedur Watson.

\section{METODE PENELITIAN}

Jenis penelitian ini merupakan penelitian deskriptif kualitatif. Subjek penelitian adalah siswa kelas IX.3 dengan jumlah 30 siswa. Untuk menentukan tipe Adversity Quotient dari subjek yang dipilih yaitu membagikan angket yang berisi 40 pernyataan, dengan penilaian skor menggunakan skala likert, menggunakaa rentang skor 1-5. 
Tabel 2. Kriteria Skor Berdasarkan Skala Likert

\begin{tabular}{cccc}
\hline No & Kriteria & Favorable & Unfavorable \\
\hline 1. & SS & 5 & 1 \\
\hline 2. & S & 4 & 2 \\
\hline 3. & TP & 3 & 3 \\
\hline 4. & KS & 2 & 4 \\
\hline 5. & TS & 1 & 5 \\
\hline
\end{tabular}

Teknik pengumpulan data pada penelitian ini menggunakan angket dan tes tertulis. Teknik anallisis data melalui reduksi data, penyajian data dan penarikan kesimpulan (Miles dan Huberman). Data hasil tes tertulis dianalisis berdasarkan prosedur Watson. Teknik keabsahan data menggunakan bahan refernsi dan triangulasi data.

\section{HASIL DAN PEMBAHASAN}

Berdasarkan hasil penelitian, diperoleh hasil jenis kesalahan yang dilakukan oleh siswa berdsarkan prosedur Watson ditinjau dari Adversity Quotient siswa sebagai berikut.

Tabel 2. Kategori Tingkat Adversity Quotient Siswa Kelas IX.3

\begin{tabular}{lcc}
\hline Kategori & Skor & Jumlah Siswa \\
\hline Climbers (Tinggi) & $166-200$ & 2 \\
\hline Climbers (Cukup) & $135-165$ & 2 \\
\hline Campers & $95-134$ & 15 \\
\hline Quitters (Kurang) & $60-94$ & 7 \\
\hline Quitters (Rendah) & $0-59$ & 30 \\
\hline Total Siswa & &
\end{tabular}

Dari tabel diatas jika di persentasekan, maka terlihat bahwa siswa yang memiliki AQ tipe Climbers (tinggi) terdapat 2 siswa dengan persentase 6.5\%, AQ dengan tipe Climbers (cukup) berjumlah 2 siswa dengan persentase 6.5\%, untuk AQ tipe Campers terdapat 15 siswa dengan persentase 48.4\%, AQ tipe Quitters (kurang) Terdapat 7 siswa persentase $22.6 \%$ dan AQ tipe Quitters (rendah) Terdapat 4 siswa dengan persentase $12.9 \%$.

Setelah diperolehnya AQ, peneliti memberikan nama pada setiap subjek dengan subjek pada AQ tipe Climbers (tinggi) yaitu CT, untuk AQ tipe Climbers 
(cukup) yaitu CP, untuk AQ tipe Campers yaitu CA, untuk AQ tipe Quitters (kurang) yaitu QK sedangkan AQ tipe Quitters (Rendah) yaitu QR. Setelah penamaan pada setiap subjek selesai, maka selanjutnya peneliti menganalisis hasil tes tertulis yang telah dikerjakan oleh siswa di SMP Darul Aitam Palembang kelas IX.3 yang berjumlah 30 siswa dengan berlandaskan prosedur kesalahan Watson. Adapun soal tes tertulis adalah sebagai berikut:

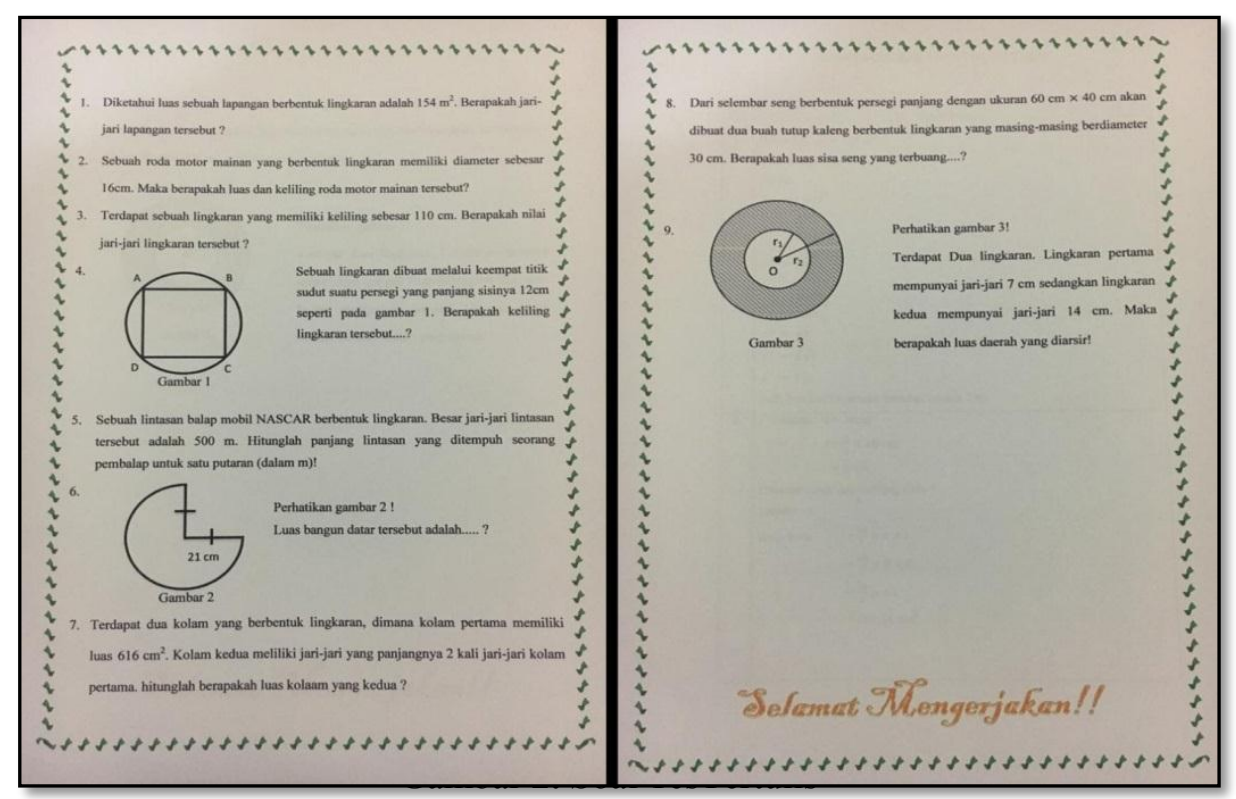

Berikut ini disajikan 5 contoh hasil pengerjaan siswa yang diambil 1 dari masing-masing yang mewakili tipe Adversity Quotient kemudian dianalisis kesalahan pengerjaan soal tersebut yang dilandaskan pada indikator kesalahan Watson.

\section{a. Subjek Climbers Tinggi (CT)}

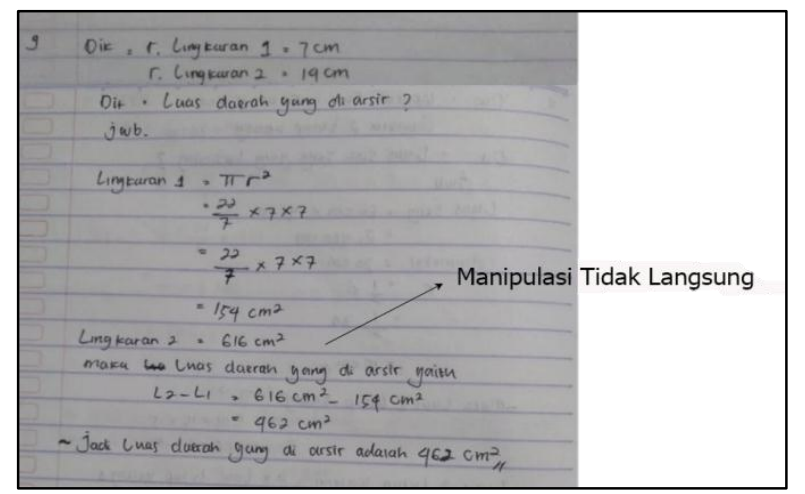

Gambar 3. Hasil Jawaban dari Salah Satu Subjek CT

Berdasarkan gambar 3, terlihat bahwa subjek CT melakukan jenis kesalahan manipulasi tidak langsung dalam menyelesaikan soal yang diberikan. Dimana subjek 
CT langsung menuliskan hasil dari luas lingkaran kedua tanpa adanya proses mendapatkan itu walaupun hasil yang didapat bernilai benar.

\section{b. Subjek Climbers Cukup (CP)}

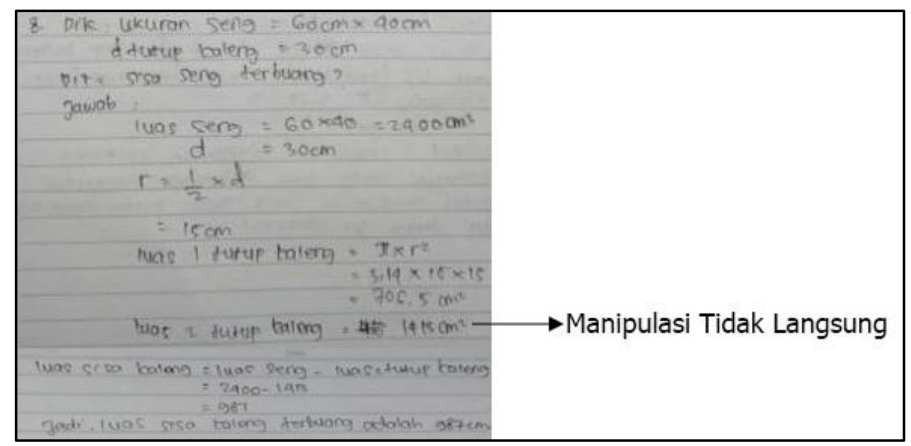

Gambar 4. Hasil Jawaban dari Salah Satu Subjek CP

Berdasarkan gambar 4, terlihat bahwa CP melakukan salah satu jenis kesalahan yaitu pada manipulasi tidak langsung dalam menyelesaikan soal yang diberikan, hal ini terlihat dari apa yang dikerjakan oleh $\mathrm{CP}$ yaitu langsung menuliskan hasil luas 2 tutup kaleng tanpa ada proses pengerjaannya atau tanpa tahu dapat dari mana nilai tersebut.

\section{c. Subjek Campers (CA)}

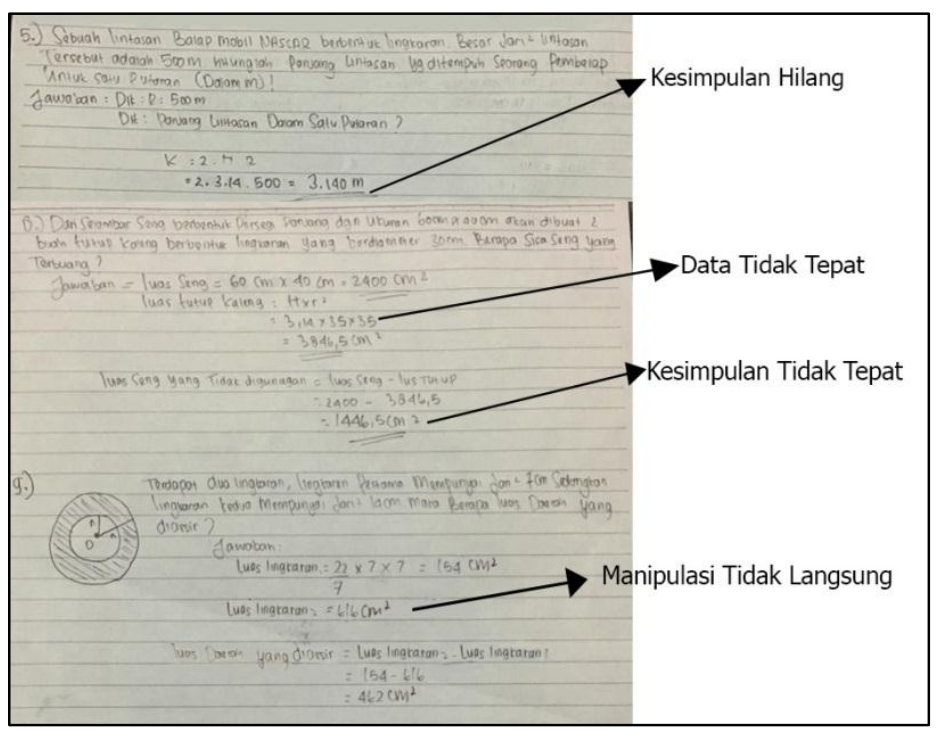

Gambar 5. Hasil Jawaban dari Salah Satu Subjek CA

Berdasarkan gambar 5, terlihat bahwa subjek CA melakukan jenis kesalahan pada soal nomor 5, 8 dan 9, dimana pada soal nomor 5 subjek CA hanya menjawab soal sampai ke tahap keliling lingkaran saja, sedangkan yang diminta soal yaitu panjang lintasan dalam satu putaran dengan demikian subjek CA dapat dinyatakaan 
melakukan jenis kesalahan kesimpulan hilang. Sedangkan untuk soal nomor 8 subjek CA melaukan jenis kesalahan data tidak tepat, dimana subjek CA memasukkan nilai jari-jari sebesar $35 \mathrm{~cm}$, sedangkan di soal dikatakan bahwa nilai diameternya yang sebesar $30 \mathrm{~cm}$ sehingga menghasilkan kesimpulan yang tidak tepat. Untuk soal nomor 9 subjek CA juga melakukan jenis kesalahan yaitu manipulasi tidak langsung, dikarenakan pada proses penyelesaian soal subjek CA langsung menuliskan hasil dari lingkaran ke dua tanpa menyertakan proses mendapatkan hasil tersebut.

\section{d. Subjek Quitters kurang(QK)}

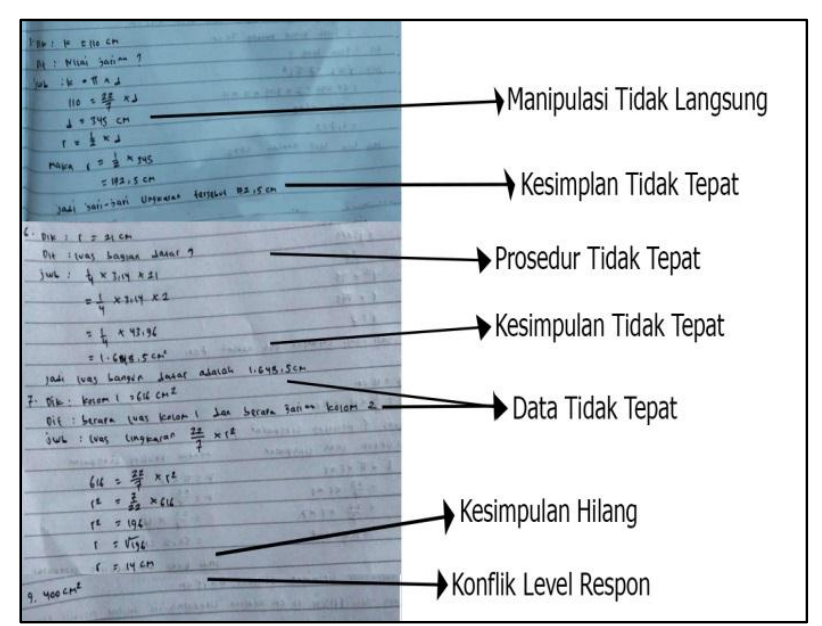

Gambar 6. Hasil Jawaban dari Salah Satu Subjek QK

Berdasarkan gambar 6, terlihat bahwa QK melakukan kesalahan dalam dalam menyelesaikan soal yang diberikan. Pada soal nomor 3, subjek QK melakukan kesalahan yaitu langsung menuliskan diameter sebesar $350 \mathrm{~cm}$ tanpa diketahui dari mana mendapatkannya, hal tersebut termasuk kedalam hal yang tidak logis dan dapat dinyatakan sebagai manipulasi tidak langsung sehingga kesimpulan atau hasil akhir yang didapat juga tidak tepat. Sedangkan pada jawaban nomor 6, subjek QK melakukan prosedur yang tidak tepat terlihat pada lembar jawaban tersebut, subjek QK menuliskan 1/4 dari luas bangunan tersebut yang semestinya bangunan tersebut terdiri dari 3/4 dari luas lingkaran dengan demikian jika prosedur yang tidak tepat maka kesimpulan atau hasil yang diperoleh tidak tepat pula. Untuk jawaban nomor 7, subjek QK tidak menuliskan data yang tepat hal ini ditandai dengan penulisan kalimat ditanya pada lembar jawaban yaitu berapa luas kolam pertama sedangkan yang ditanya yaitu berapa luas dari kolam kedua dan juga di lembar jawaban dituliskan di bagian ditanya yaitu berapa jari-jari kolam kedua yang semestinya hal 
itu harus dituliskan di dalam pernyataan diketahui, dengan demikian subjek QK tidak mampu menuliskan data yang tepat. Selanjutnya dalam menjawab soal, subjek QK tidak meneruskan proses pengerjaan melainkan hanya menemukan jari-jari lingkaran yang tidak diketahui jari-jari lingkaran ke berapa yang diperolehnya pada lembar jawaban tersebut, dengan demikian dapat disimpulkan bahwa subjek QK melakukan jenis kesalahan yaitu kesimpulan yang hilang.

\section{e. Subjek Quitters rendah $(\mathrm{QR})$}

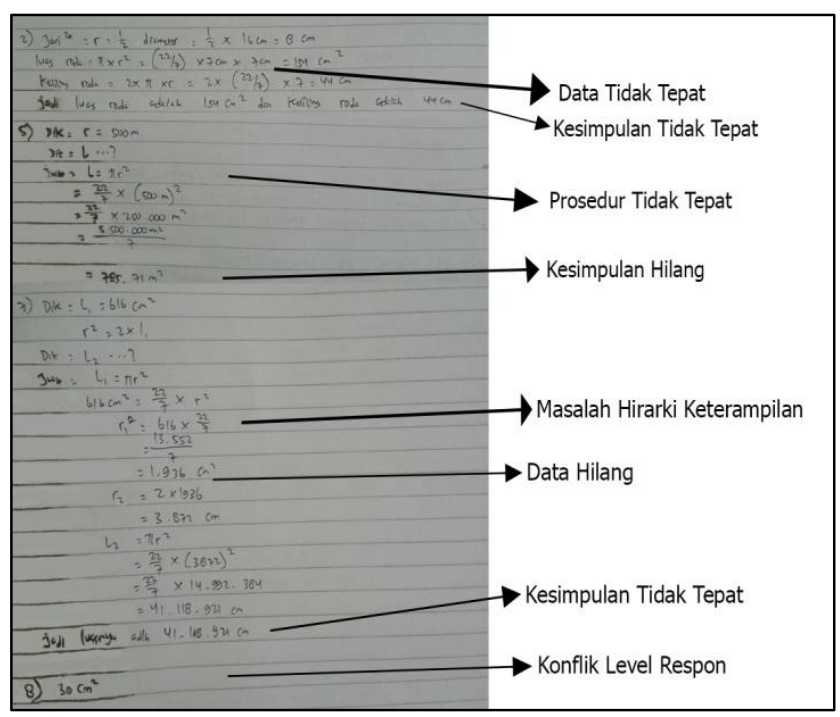

Gambar 7. Hasil Jawaban dari Salah Satu Subjek QR

Berdasarkan gambar 7, terlihat bahwa CA melakukan kesalahan dalam menyelesaikan soal yang diberikan. Pada soal nomor 2, bisa dilihat bahwa subjek QR pada saat proses pengaplikasian rumus menggunakan data yang telah diketahui, subjek QR memasukkan data yang tidak tepat, hal ini bisa dilihat dari baris kedua dari lembar jawaban tersebut dimana subjek QR memasukkan data dengan nilai jarijari sebesar $7 \mathrm{~cm}$ sedangkan nilai jari-jari yang sudah diproses menggunakan data diameter memiliki nilai sebesar $8 \mathrm{~cm}$ dengan demikian jika subjek QR memasukkan data yang tidak tepat maka kesimpulan atau hasil yang diperoleh dari penyelesaian soal tersebut juga tidak tepat. Sedangkan pada jawaban nomor 5, Subjek QR melakukan prosedur yang tidak tepat dalam menyelesaikan soal, hal ini sejalan dengan rumus yang ditulis untuk menjawab soal tersebut yaitu luas lingkaran sedangkan prosedur yang benar yaitu menuliskan atau memproses rumus dari keliling lintasan balap yang berbentuk lingkaran lalu digiring menggunakan rumus mencari panjang dari lintasan tersebut. Karena subjek QR tidak menggunakan 
prosedur yang tepat dalam menjawab soal maka kesimpulan yang didapat hilang karena data yang diproses itu menggunakan rumus dari luas lingkaran dan tidak dilanjutkan dalam memperoleh panjang lintasan yang ditumpuh satu kali putaran. Pada soal nomor 7, subjek QR memiliki masalah hirarki keterampilan karena subjek QR tidak bisa mengubah rumus luas lingkaran menjadi rumus jari-jari lingkaran seperti yang terlihat dari lembar jawaban tersebut dan terdapat data yang hilang dalam proses penyelesaian soal tersebut. Kemudian jika proses pengubahan rumus tersebut tidak tepat maka proses selanjutnya dalam menjawab soal juga tidak tepat sehingga hasil akhir atau kesimpulan yang didapat juga tidak tepat.

Dengan demikian dapat dilihat bahwa penelitian yang dilakukan ini sejalan dengan apa yang dikatakan oleh Stolz (2000) yaitu AQ tipe Climbers merupakan tipe yang mempunyai kemampuan untuk menghadapi kesulitan yang ada, hal ini dibuktikan oleh hasil yang diteliti oleh peneliti bahwa siswa yang memiliki AQ tipe Climbers melakukan kesalahan hanya 1 dari 8 kesalahan dalam menyelesaikan permasalahan atau soal yang diberikan. Sedangkan untuk siswa yang mempunyai AQ pada tipe Campers, Stolz mengatakan bahwa individu tersebut lumayan baik dalam menempuh atau menyelesaikan permasalahan yang ada, hal ini sependapat dengan hasil yang didapat peneliti pada penelitian ini yaitu siswa yang memiliki AQ Campers cenderung melakukan 4 dari 8 jenis kesalahan yang dilandaskan pada teori kesalahan Watson. Untuk individu yang memiliki AQ dengan tipe Quitters cenderung menyerah terhadap tantangan atau masalah yang ada, hal ini sejalan dengan hasil dari penelitan yang dilakukan peneliti, yang ditandai dengan hampir semua kesalahan dilakukannya yaitu 7 dari 8 kesalahan dalam menjawab soal yang diberikan.

\section{SIMPULAN}

Berdasarkan hasil analisis dan pembahasan yang telah dipaparkan, maka dapat disimpulkan bahwa :

1. Siswa yang memiliki Adversity Quotient tipe Climbers (tinggi maupun cukup) melakukan jenis kesalahan dalam menyelesaikan soal materi keliling dan luas lingkaran berdasarkan prosedur Watson yaitu manipulasi tidak langsung (undirected manipulation/UM). 
2. Pada siswa yang memiliku Adversity Quotient tipe Campers cenderung melakukan 4 jenis kesalahan dalam menyelesaikan soal materi keliling dan luas lingkaran berdasarkan prosedur Watson yaitu data tidak tepat (inappropriate data/IN), kesimpulan hilang (omitted conclusion/OC), manipulasi tidak langsung (undirected manipulation/UM) dan kesimpulan yang tidak tepat (above other/AO).

3. Pada siswa yang memiliki Adversity Quotient tipe Quitters (kurang) cenderung melakukan 6 jenis kesalahan dalam menyelesaikan soal materi keliling dan luas lingkaran berdasarkan prosedur Watson yaitu data tidak tepat (inappropriate data/IN), kesimpulan hilang (omitted conclusion/OC), prosedur tidak tepat (inappropriate procedure/IP), konflik level respon (response level conflict/RLC), manipulasi tidak langsung (undirected manipulation/UM) dan kesimpulan tidak tepat, tidak menjawab soal (above other/AO). Sedangkan untuk siswa yang memiliki Adversity Quotient tipe Quitters (rendah) melakukan 7 jenis kesalahan dalam menyelesaikan soal materi keliling dan luas lingkaran berdasarkan prosedur Watson yaitu data tidak tepat (innappropriate data/IN), prosedur tidak tepat (inappropriate procedure/IP), data hilang (omitted data/OD), masalah hirarki keterampilan (skills hierarchy problem/SHP), kesimpulan hilang (omitted conclusion/OC), konflik level respon (response level conflict/RLC) dan kesimpulan tidak tepat, tidak menjawab soal (above other/AO).

\section{REFERENSI}

Arifin, Y. T. 2011. Analisis Kesalahan Sisa Kelas VIII SMP N 10 Semarang dalam Menyelesaikan Soal Matematika pada Materi Pokok Lingkaran dengan Panduan Kriteria atson . Skripsi, 1-98.

Azwar, S. 2015. Penyusuanan Skala Psikologi Edisi 2 . Yogyakarta: Pustaka Pelajar.

Hidayat, W., \& Sarinigsih, R. 2018. Kemampuan Pemecahan Masalah Matematis dan Adversity Quotient Siswa SMP Melalui Pembelajaran Open Ended. Jurnal Nasional Pendidikan Matematika, Vol.2(1) : 112-113. 
Matore, M. a. 2015. The Influence of AQ on The Academic Achievement among Malaysian Polytechnic Student. International Education Studies, Vol.8(6) : 69-74.

Nur'aini, I. L., Harahap, E., Badruzzaman, F. H., \& Darmawan, D. 2017. Pembelajaran Matematika Geometri Secara Realistis Dengan GeoGebra. Jurnal Matematika, Vol.16(2) : 1-6.

Pratiwi, Y. C. 2016. Analisis Kemampuan Pemecahan Masalah Matematika Siswa SMP dalam Pembelajaran Creative Problem Solving Ditinjau Dari Adversity Quotient. Skripsi, 1-326.

Saputri, R. R., Sugiarti, T., Murtikusuma, R. P., Trapsilasiwi, D., \& Yudianto, E. 2018. Analisis Kesalahan Siswa Dalam Menyelesaikan Soal Materi Fungsi Berdasarkan Kriteria Watson Ditinjau Dari Perbedaan Gender Siswa SMP Kelas VIII. Jurnal Kadikma, Vol.9(2), 59-68.

Sari, I. W. 2018. Analisis Kesalahan Mahasiswa Dalam Menyelesaikan Soal Trigonometri Berdasarkan Kriteria Watson. Jurnal Widyaloka ,Vol. 5(2), 142.

Stoltz, P. G. 2000. Adversity Quotient Mengubah Hambatan Menjadi Peluang. Jakarta: Grasindo

Wardiana, I. e. 2014. Hubungan antara Adversity Quotient (AQ) dan Minat Belajar dengan Prestasi Belajar Matematika pada Siswa Kelas V SD di Kelurahan Pendungan. Jurnal Mimbar PGSD Universitas Pendidikan Ganesha, Vol.2(1) : 24-34. 